Article

\title{
Language Planning and Policy, Law and (Post)Colonial Relations in Small Island States: A Case Study
}

\author{
Herman Bröring ${ }^{1, *}$ and Eric Mijts ${ }^{2,3,4}$ \\ ${ }^{1}$ Faculty of Law, University of Groningen, 9712 EK Groningen, The Netherlands; E-Mail: h.e.broring@rug.nl \\ ${ }^{2}$ Faculty of Law, University of Aruba, Oranjestad, Aruba; E-Mail: eric.mijts@ua.aw \\ ${ }^{3}$ Faculty of Arts, University of Antwerp, 2000 Antwerp, Belgium \\ ${ }^{4}$ Faculty of Arts and Philosophy, University of Ghent, 9000 Ghent, Belgium \\ * Corresponding author
}

Submitted: 15 August 2017 | Accepted: 16 October 2017 | Published: 22 December 2017

\begin{abstract}
Language planning and policy (LPP) in postcolonial island states is often strongly (co)determined by the former colonizer's state tradition. Comparable to the examples of the development of LPP in Cabo Verde (Baptista, Brito, \& Bangura, 2010), Haiti (DeGraff, 2016), and Mauritius (Johnson, 2006; Lallmahomed-Aumeerally, 2005), this article aims to illustrate and explain in what way the current situation of the dominance of Dutch in governance, law and education in Aruba (and Curaçao) can only be explained through path dependency and state tradition (Sonntag \& Cardinal, 2015) in which, time and again, critical junctures, have not led to decisions that favour the mother tongue of the majority of the population (Dijkhoff \& Pereira, 2010; Mijts, 2015; Prins-Winkel, 1973; Winkel, 1955). In this article, three perspectives on LPP in small island states are explored as different aspects of the continuation of the former colonizer's state tradition and language regime. The first part will focus on the (non-)applicability of international treaties like the European Charter for Regional or Minority Languages (ECRML) on the challenges of small island states. The point will be made that international treaties, like the ECRML, do not (currently) provide sufficient basis for the protection of languages in former colonial islands and for the empowerment of individuals through language rights. The second part explores the meaning of fundamental legal principles and specific demands, deduced from international treaties. The point will be made that the structure of the Kingdom of the Netherlands brings with it several limitations and obstacles for the autonomous development of LPP. The third part will focus on the way in which current Aruban legislation reflects the dominance of Dutch in governance, the judiciary and education. While bearing in mind that choices for legislation on language for governance, the judiciary and education are rooted in very diverse principles, a critical reading of existing legislation reveals an interesting dynamic of symbolic inclusive legislation and exclusive practices through language restrictions that favour the Dutch minority language. Recent research, however, demonstrates that law/policy and practice are not aligned, as such creating an incoherent situation that may call for a change in legislation and policy.
\end{abstract}

\section{Keywords}

colony; Dutch; island; language; law; planning; policy

\section{Issue}

This article is part of the issue "Multilingualism and Social Inclusion", edited by László Marácz (University of Amsterdam, The Netherlands/Gumilyov Eurasian National University, Kazakhstan) and Silvia Adamo (University of Copenhagen, Denmark).

(C) 2017 by the authors; licensee Cogitatio (Lisbon, Portugal). This article is licensed under a Creative Commons Attribution 4.0 International License (CC BY).

\section{Introduction}

Language planning and policy (LPP) in postcolonial island states is often strongly (co)determined by the former colonizer's state tradition. Comparable to the exam- ples of the development of LPP in Cabo Verde (Baptista, Brito, \& Bangura, 2010), Haiti (DeGraff, 2016), and Mauritius (Johnson, 2006; Lallmahomed-Aumeerally, 2005), this article aims to illustrate and explain in what way the current situation of the dominance of Dutch in gov- 
ernance, law and education in the Caribbean parts of the Kingdom of the Netherlands can only be explained through path dependency and state tradition (Sonntag \& Cardinal, 2015) in which, time and again, critical junctures, have not led to decisions that favour the mother tongue of the majority of the population (Dijkhoff \& Pereira, 2010; Mijts, 2014, 2015; Prins-Winkel, 1973; Winkel, 1955). The lack of legal acceptance and consolidation of creole languages is illustrative of the dominance of the languages of the former colonizer in the decolonized Caribbean islands but also in other decolonized small island states and decolonized areas. Even though often the vast majority of the population of these countries does not speak the language of the former colonizer as a home language, that language is chosen and maintained as the official language. The home language often does not get official status.

Decolonized small island states face special challenges in the development of language policy and planning for education, government and law. These challenges are often similar to the ones faced by larger decolonized states, but the scale often restricts rational development of a policy that fits the needs of that specific community. In most cases, the state tradition of the former colonizer is followed, adopting the former colonizer's constitutional and legal framework as well as the educational system and most of the educational language policy. Innovation in the different domains of language use in the public sector in these countries is likely to follow the developments of the former colonizer's systems. Quality control-either in government, the judiciary or the educational system-follows the tracks of the former colonizer's systems, and often, the quality control agencies of the former colonizer are invited to impose their frameworks on the small island state's systems. The private sector institutions appear to follow their own paths, developing their own language practice in all three domains, even including the development of-sometimes problematic-contracts that are not composed in the language of the law (the colonial heritage language) but in English. As such, the development of language policy and planning in the public and private sectors are running at different speeds and in different directions, resulting in a disconnect between the educational system and societal practice.

In this article, three perspectives on LPP in small island states are explored as different aspects of the continuation of the former colonizer's state tradition and language regime. The first part will focus on the (non)applicability of international treaties like the European Charter for Regional or Minority Languages (ECRML) on the challenges of small island states. The point will be made that international treaties, like the ECRML, do not (currently) provide sufficient basis for the protection of languages in former colonial islands and for the empowerment of individuals through language rights. The second part explores the meaning of fundamental legal principles and specific demands, deduced from international treaties. The point will be made that the structure of the Kingdom of the Netherlands brings with it several limitations and obstacles for the autonomous development of LPP. The third part will focus on the way in which current Aruban legislation reflects the dominance of Dutch in governance, the judiciary and education. While bearing in mind that choices for legislation on language for governance, the judiciary and education are rooted in very diverse principles, a critical reading of existing legislation reveals an interesting dynamic of symbolic inclusive legislation and exclusive practices through language restrictions that favour the Dutch minority language. Recent research, however, demonstrates that law/policy and practice are not aligned, as such creating an incoherent situation that may call for a change in legislation and policy.

Numerous publications point out that the way in which the Caribbean islands of the Kingdom of the Netherlands deal with their multilingual populations is sub-optimal and that a revision of the policies and practices in governance, the judiciary and education would be greatly beneficial to the populations of these islands. Many of the publications from a legal perspective focus on criminal proceedings (Raad voor de Rechtshandhaving, 2017; Reintjes, 2010; Van der Velden, 2008), but criminal law is only a very small aspect of the language policy and law conundrum that affects the population of the islands; accessibility through language of governance and education are key factors in socio-economic inclusion (e.g., Liasidou, 2012; Tollefson, 2013a, 2013b) and the language of policies, ordinances and official publications is not regulated. As we will demonstrate in the case study of language legislation in the Kingdom and in Aruba that follows, minimum legal guarantees have been created for language use by the government, but no clear inclusive policy has been developed. Language policy and language practice are often not aligned, as in practice individual language skills often enable the accommodation of linguistic diversity in civilian-government interactions, but these practices do not offer the civilians guarantees for access through language facilities. Insufficient data is currently available on the extent of inclusive language practices in these domains in the Caribbean islands of the Kingdom of the Netherlands nor the translation of these practices into policy and legislation. Multiple publications point out that current language policy and practice in the Caribbean part of the Kingdom of the Netherlands is not yet inclusive and considerable changes are necessary in order to improve access and socio-economic mobility through language (e.g., Garrett, 2008; Mijts, Kester, Lozano Cosme, \& Faraclas, 2014; Pereira, 2012). Insufficient multidisciplinary research programs have been effected yet that can lead to socially acceptable research data that can help policy makers make successful decisions on LPP. The importance of such multidisciplinary research agendas for the development and acceptance of inclusive language policies in other multilingual societies has been sufficiently demonstrated by long-term projects like the Flemish- 
South African Studies in Language Policy in South Africa of Du Plessis, Deprez, Cuvelier, Meeuwis, Webb and others, Ricento and Bale's Multidisciplinary Approaches to Language Policy and Planning, or Tonkin's study group Language and the UN.

For a better understanding of LPP in the Caribbean countries and territories of the Kingdom of the Netherlands, some information has to be provided on the quasifederal structure of the Kingdom. The Kingdom consists of four countries, namely the Caribbean countries of Aruba, Curaçao and St Maarten, and the Country of the Netherlands. It is important to bear in mind that the Country of the Netherlands is just one of the four Countries of the Kingdom of the Netherlands. The three Caribbean countries are rather small: they have only 40.000 (St Maarten), 105.000 (Aruba) and 160.000 (Curaçao) inhabitants; the Country of the Netherlands has 17.000.000 inhabitants. Since 2010, when a restructuring within the Kingdom took place (the Country of the Netherlands Antilles was dismantled), the much smaller islands Bonaire, Statia and Saba, with 17.000, 3550 and 2000 inhabitants, respectively, became part of the Country of the Netherlands. ${ }^{1}$ Therefore the Country of the Netherlands has a European part as well as a Caribbean part, the so-called Caribbean territories. ${ }^{2}$ The relations between the three Caribbean countries and the Country of the Netherlands, as well as the relations between the European part and the Caribbean territories of this country, are complicated for a variety of reasons that will be examined below.

Discussions on LPP focus on many different topics including culture, identity, religion, economy, technical questions, etc. While recognizing the validity of the discussions on these topics and domains of language use, in this article we focus on the interaction and tension between language of and in policy and law in the achievement of an inclusive society.

In this article, we first consider the minimal guarantees and opportunities as presented in international treaties. Subsequently we examine the role of the Kingdom of the Netherlands and the structure of the Kingdom in the development of LPP, and finally we discuss language legislation in Aruba as a case study of law as discourse on LPP. In the conclusion we propose a new multidisciplinary research agenda for the study of the relation between language, policy, law and practice for inclusive island societies.

\section{International Treaties and LPP}

Some international treaties applicable to the Kingdom of the Netherlands and its four countries contain minimal guarantees and opportunities for LPP. These treaties can be categorized as follows. Firstly, there are treaties which have direct relevance for LPP, whereas others only have indirect relevance. Secondly, some treaties are binding, whereas others are not. A distinction may also be made between treaties and principles which address individual rights and those which address group rights, especially minorities.

Article 2 of the UN Declaration on the Rights of Persons Belonging to National or Ethnic, Religious and Linguistic Minorities, establishes the right of minorities to use their own language, and the right to effective communication and participation. However, this declaration is not binding. Article 27 of the UN International Covenant on Civil and Political Rights (ICCPR) reads: 'In those States in which ethnic, religious or linguistic minorities exist, persons belonging to such minorities shall not be denied the right, in community with the other members of their group, to enjoy their own culture, to profess and practice their own religion, or to use their own language.' The ICCPR is binding but its relevance is relative, since it is actually Dutch which is the language of a minority, not Papiamento (Leeward Islands) or English (Windward Islands).

Binding, too, are some fundamental rights established in treaties: the protection of private life, the freedom of expression, association and assembly, the right on political participation, the principle of democracy, the principle of non-discrimination, and the principle of equality. These are fundamental rights in the ICCPR as well as in the European Convention for the Protection of Human Rights and Fundamental Freedoms (ECHR) and in the European Charter on Fundamental Rights of the European Union. ${ }^{3}$

It is well-known that there are also special legal demands in case of a criminal charge or prosecution, inter alia in the ECHR, namely in Article 5.2: 'Everyone who is arrested shall be informed promptly, in a language which he understands, of the reasons for his arrest and of any charge against him.' Furthermore Article 6.3 states that: 'Everyone charged with a criminal offence has the following minimum rights: (a) to be informed promptly, in a language which he understands and in detail, of the nature and cause of the accusation against him;...(e) to have the free assistance of an interpreter if he cannot understand or speak the language used in court.'

These provisions for a criminal charge or prosecution are adopted (repeated) in legislation of the countries of the Kingdom. ${ }^{4}$ The wording and the level of guarantees are, in fact, the same, alluding to the use of a language the prosecuted person can understand (instead of his mother tongue). This is particularly important for

\footnotetext{
${ }^{1}$ Being realistic, not disrespectful: as left-overs.

2 The Kingdom of the Netherlands is Member of the European Union. Nevertheless, European law is only fully applicable in the continental European part of the Kingdom. Since the beginning of the European Union, all Caribbean islands have had Overseas Countries and Territories (OCT) status. Today they still have this status. At the same time the people of the OCTs of the Kingdom have European citizenship.

${ }^{3}$ The European Charter is possibly applicable to the Caribbean countries and territories (all OCT) in relation to European citizenship of the inhabitants of the countries and territories.

${ }^{4}$ See, e.g., Article 1.5, Section 3, sub a, Staatsregeling Aruba, and Article 28, Section 4, sub a, Staatsregeling St Maarten.
} 
the Caribbean countries and territories of the Kingdom where, as we will explain, Dutch is the dominant language in criminal (and other) court procedures.

It is indisputable that in case of a criminal charge or prosecution extra guarantees are applicable. Moreover, discussion on language and law pertains relatively often to criminal law, not administrative or civil law (although quantitatively people are dealing considerably more often with administrative and civil law).

The implementation and enforcement of binding treaties pertain to powers of the government of the autonomous countries of the Kingdom. The Kingdom has no power in this domain. There is one exception. When a breach of a treaty implies a breach of principles of good governance and the Rule of Law, the government of the Kingdom (in practice the Dutch government) has the power to intervene. ${ }^{5}$ There are currently no examples of this type of infringement by a country of the Kingdom with regards to a treaty provision concerning LPP as such. This is not surprising, considering that the treaties involved contain minimal guarantees.

\section{The Kingdom and Its Limitations and Obstacles for LPP}

\subsection{Preliminary Remarks}

LPP has to be in accordance with language rights in treaties and fundamental legal principles such as accessibility to law, foreseeability of law and legal certainty, the equality principle, transparency and participation. ${ }^{6}$ The previous section of our contribution clarifies that most treaties do not contain firm and binding guarantees for LPP. Fundamental legal principles are binding. They are particularly important for social inclusion. Those who have no access to the law, for example, can be excluded from their rights and treated differently from those who do have access and are able to realise their rights. An infringement of the equality principle implies that an individual person or a group of persons is legally and socially excluded. Fundamental legal principles are the foundations of a society that bridge law and sociology.

Fundamental legal principles are vague and need interpretation. This involves much leeway or, in legal jargon, discretion. In discretionary cases the prominent question is which authority has the responsibility to interpret and apply the vague principles involved. Regarding the Caribbean islands of the Kingdom of the Netherlands, the answer is clear: the governments of the (autonomous) countries of the Kingdom are competent. However, these governments, especially those of the Caribbean countries, encounter difficulties as a consequence of legal and political relations within the Kingdom; the integration of these countries in the Kingdom entails limitations and obstacles for LPP, de jure as well as de facto.

\subsection{The Kingdom, the Caribbean and the Influence from the European Netherlands}

The first reason pertains to the constitutional make-up and powers of the Kingdom. This make-up and these powers are laid down in the Charter of the Kingdom. This Charter qualifies the principal authorities from the Country of the Netherlands, namely the King, the Parliament, the government and the Council of State, as authorities of the Kingdom, some of them supplemented with members from the Caribbean countries. This implies that constitutionally the position of the Country of the Netherlands is very dominant: there is an imbalance in power between the Country of the Netherlands and the Caribbean countries. ${ }^{7}$ The explanation for this is quite simple, namely the big difference in size between the Country of the Netherlands and the Caribbean countries.

On the other hand, the powers of the Kingdom are narrow. ${ }^{8}$ It is crystal clear that LPP is a country issue, not a concern for the Kingdom. Only when it is evident that treaty law or a fundamental principle like accessibility to law, legal certainty or the equality principle is violated, the Kingdom is permitted to apply its power. Such principles are violated when it appears that, as a consequence of insufficient language provisions, groups of people are excluded from (information about) social aid or licences, for example. In the Caribbean countries there is no tradition of (empirical self-)evaluation. Indications that the current LPP implies an urgent problem of exclusion of groups of people are weak (if any indication exists). Contrary to criminal law procedures, where specific guarantees are applicable, this is especially true for governance and public administration. Even if there is a hidden problem, there is not any motive for the Kingdom to intervene. Only when a Caribbean country infringes treaty law or fundamental legal principles, does the Kingdom have the power to intervene. It is important to note that, according to Article 50 of the Charter, it is only when a Caribbean country violates such a norm that the Kingdom's power to intervene is applicable. In case of violation by the Country of the Netherlands, the Kingdom has no power to intervene. This can be seen as an expression of the big overlap between the Kingdom and the Country of the Netherlands. ${ }^{9}$ It does not matter, because it is very likely that the Kingdom will not interfere with Caribbean LPP.

The second reason for the complexity of the relations within the Kingdom and with respect to the Country of the Netherlands is the colonial history of the Kingdom. It goes without saying that the colonial period left its marks, or more precise, its scars. As a result, the Kingdom (officially the Kingdom's government, in practice

\footnotetext{
5 See Article 43 of the Charter of the Kingdom.

${ }^{6}$ The latter as an aspect of democracy.

${ }^{7}$ And between the European part and the Caribbean territories of the Country of the Netherlands.

8 See Article 3 of the Charter.

${ }^{9}$ Cf. Santos do Nascimento (2017, p. 287). Santos do Nascimento concludes that the Kingdom of the Netherlands is still a colonial state.
} 
the Dutch government) is very reluctant to intervene in the Caribbean countries, especially where culture and languages are at stake. With respect to LPP, the Kingdom has never officially intervened and any discussion to do so has never arisen.

Certainly, another result of the colonial history is the dominance of the Dutch language (although a minority language) for Caribbean legislation, governance and judiciary. The legislation of the Caribbean countries states that Dutch and Papiamento (Aruba), ${ }^{10}$ Dutch, Papiamento and English (Curaçao), ${ }^{11}$ or Dutch and English (St Maarten) ${ }^{12}$ are the official languages. ${ }^{13}$ The Caribbean legislation is always in Dutch. ${ }^{14}$ The predominant role of Dutch is not only a residue of colonial times. Even today there are intelligible explanations for this role of Dutch, at least where legislation and the judiciary are at stake. Regarding legislation it must be recognized that the law of the three Caribbean countries is strongly inspired by the law of the European Netherlands: the Dutch law from The Hague (Dutch government city) can be seen as legal transplants in the Caribbean. To put it briefly, legislation of the three Caribbean countries is usually a previous version of Dutch legislation.

The legislation regarding language in the judiciary is as follows. The starting point is the Rijkswet Gemeenschappelijk Hof van Justitie (the Kingdom legislation on the Caribbean judiciary). This legislation establishes Courts of First Instance (Gerecht in Eerste Aanleg, GEA) and a High Court (Gemeenschappelijk Hof van Justitie, GHvJ), with the possibility of an appeal in cassation at the Supreme Court (Hoge Raad) in The Hague. The language of procedure is one of the official languages. In practice this is often Dutch. The decision of all courts is always in Dutch. ${ }^{15}$ The dominant position of Dutch as the judiciary language has to do with the participation of Dutch judges in the Caribbean judiciary.

Closely connected to the above-mentioned imbalance in power and the phenomenon of legal transplants, there is another relevant aspect, namely the small state character of the Caribbean countries. From a global perspective the Country of the Netherlands is a rather small country. Nevertheless, within the framework of the Kingdom this country is by far the biggest country and has by far the most human and financial resources needed for law-making. In the prevailing constitutional and political view, it is emphasised that the Kingdom of the Netherlands consists of four equal countries. ${ }^{16}$ Actually, the Dutch influence in the Caribbean countries of the
Kingdom is very strong, inter alia where legislation (legal transplants) and judiciary (Dutch judges) are involved. This is enhanced by the so-called concordance principle of Article 39 of the Charter, which says that in all countries of the Kingdom private, criminal and other law, mainly administrative law, must be regulated in a corresponding manner. So, there is a legal mission of legal convergence; legal items should be as much as possible regulated in the same way in all the countries of the Kingdom. Caribbean law as a set of legal transplants from Dutch law and the participation of Dutch judges in the Caribbean judiciary effectuate the reality of the concordance-principle.

Is therefore the use of Dutch in Caribbean legislation and legal procedures unavoidable? From a legal point of view, the answer is no. The concordance principle does not compel the use of unidirectional legal transplants, let alone the use of Dutch in legislation and the judiciary. Translations are always an alternative; however, the law is a profession of words. From this perspective, a dominant position of English, and especially Papiamento, can be a real obstacle for the participation of Dutch judges in the Caribbean judiciary, since they are typically employed in the Caribbean for only a few years.

Hitherto, this question has not been discussed profoundly. In the past some debates took place, but in the end it seems as if the use of Dutch is taken for granted. The main reason behind this acceptance of the dominant position of the Dutch language seems to be a pragmatism where small scale societies are involved. Illustrative (and remarkable) is the report Consequenties van Meertaligheid voor de rechtshandhaving in Caribisch Nederland (Consequences of multilingualism for law enforcement in the Dutch Caribbean territories), published by the Raad voor de Rechtshandhaving (Law Enforcement Council). ${ }^{17}$ This council states that in the Dutch Caribbean territories 'the exception is the rule': normally the national language is the language in law enforcement, whereas in the Caribbean territories Dutch is the formal language of law. Most striking is the overall conclusion that the Council finds no reason to discuss Dutch being the formal language of law. The fundamental and practical arguments for such a change do not weigh up against the fundamental and practical objections. ${ }^{18}$ This main conclusion, that there is no reason for even discussing the issue, has been adopted by the Minister of Safety and Justice. ${ }^{19}$

The report of the Law Enforcement Council on multilingualism concerns the Dutch Caribbean territories

\footnotetext{
10 Article 2 Landsverordening officiële talen Aruba.

11 Article 2 Landsverordening officiële talen Curaçao.

12 Article 1 lid 2 Staatsregeling Sint Maarten; article 2 Landsverordening officiële talen Sint Maarten

13 In the territories Bonaire, Statia and Saba, which are a part of the Country of the Netherlands the official language is Dutch and Papiamento (Bonaire) or English (Statia, Saba). See Invoeringswet BES hoofdstuk 2b, 'De taal in het bestuurlijk verkeer').

14 Whereas the discussion in Parliament about this legislation is in Papiamento or English.

15 Article 9 Rijkswet Gemeenschappelijk Hof van Justitie.

16 Completely different is the view of Ryçond Santos do Nascimento, in his dissertation of 2017.

17 March 2017. Appendix of TK 2016/17, 29 279, nr. 392. With summary, examination and recommendation in English (pp. 12-18), and in Papiamento (pp. 19-24).

18 Appendix, p. 13.

19 In his letter of 3 July 2017 to the Parliament, TK 2016/17, 29 279, nr. 392
} 
(from the Country of the Netherlands), but one may say that its arguments pro and con the use of Dutch instead of Papiamento or English are applied mutatis mutandis in the context of the Caribbean countries of the Kingdom.

The language regulation is most pronounced on legislation and the judiciary. For governance, Dutch, Papiamento and/or English qualify as official languages. In the practice of public administration Papiamento and English are often used. For the Caribbean territories it is stated in legislation that Dutch is the main official language, and that Papiamento and English can be used too, sometimes, unless this is a disproportionate burden for governance. ${ }^{20}$

At the Kingdom level it is stated that Dutch is the leading judiciary language. At the level of the Caribbean countries, choices are made about the use of languages for legislation and communication between the public administration and the citizens, and within the public administration. ${ }^{21}$ Overall, the dominance of Dutch is striking.

\subsection{Multilingualism and the Future of the Kingdom}

It is rather evident that LPP in the Caribbean countries and territories of the Kingdom of the Netherlands still have sharp colonial features. Moreover, LPP is a responsibility of the (autonomous) countries of the Kingdom, not a task of the Kingdom. In this respect, the Kingdom has no limitations or obstacles for a shift to a stronger position for Papiamento or English (and Spanish). One can easily jump to the conclusion that change is desirable and necessary, but it is not that simple; there are diverse concerns and even implications for the future of the Kingdom.

Practical concerns are, for e.g., the need for more interpreters, the availability of law literature and study materials about the law of the Caribbean countries in Papiamento or English, and financial aspects. A practical and essential concern is how to organise an independent and impartial judiciary where the role of Dutch judges possibly comes under pressure when these judges have to switch over to Papiamento (regarding English the problem probably can be overcome). In the Caribbean countries and territories the need for judges from the European part of the Country of the Netherlands is generally accepted. It must be recognised that the Caribbean countries and territories of the Kingdom of the Netherlands are small scale societies. As a consequence, in general, it is difficult to suppress partiality and nepotism. The Caribbean people are aware of this. Although they complain about the dominance of judges from the European part of the Country of Netherlands, most of them accept the necessity of these impartial and independent judges for the sake of the Rule of Law and the economy, in particular the tourism sector. This also applies to an important dimension of governance, namely oversight, where co-operation between supervisory authorities of different countries of the Kingdom is generally appreciated.

In the long run the development of a law system in the Caribbean countries in Papiamento or English can reduce co-operation in the field of governance (supervision) and the judiciary. As a consequence, the concordance principle can be harmed. It may be that the concordance principle and the (colonial or idealistic?) ideas connected with this principle are the greatest obstacles for changes in LPP. Leaving behind this principle and these ideas may conjure up an image of four (autonomous) countries drifting apart, with an uncertain future for the Kingdom itself. On the other hand one can argue that court (and supervisory) procedures are very exceptional and therefore cannot be a decisive criterion for LPP in the Caribbean.

\section{Law as Discourse: What Aruban Legislation Tells Us About the Position of and the Relation between the Official Languages of Aruba}

This section will focus on the way in which current Aruban legislation reflects the dominance of Dutch in governance, the judiciary and education. While bearing in mind that choices for legislation on language for governance, the judiciary and education are rooted in very diverse principles, a critical reading of existing legislation reveals an interesting dynamic of symbolic inclusive legislation and exclusive practices through language restrictions that favour the Dutch minority language. Recent publications, however, demonstrate that law/policy and practice are not aligned, as such creating an incoherent situation that may call for a change in legislation and policy to better fit reality. In the following lines, we will present a non-exhaustive deconstruction of Aruban legislation on language from a decolonization perspective in which, following Ball (1993, p. 13), the textual interventions of the law are not only seen as agents of change, but also as agents of the way things stay the same or of the way change is different in different settings andpossibly-different from the intentions of policy authors.

The Papiamento language, the home language of about $68 \%$ of the population in Aruba, is one of the two official languages of the island state, next to Dutch, which is the home language of $6 \%$ of the population. Before 2003, Dutch was the only official language in Aruba; since that date, both languages have official status. In many publications, this status of Papiamento is acclaimed as Papiamento having the same legal status as Dutch and as such having full legal recognition. In practice this is not the case. The dominance of Dutch in governance, the judiciary and education is usually explained through the importance of the Dutch language for unity and uniformity in the Kingdom of the Netherlands, the role of Dutch as the language of the supreme court of the Kingdom of the Netherlands which is the highest court for the Aruban

\footnotetext{
20 Article 4b-4j Invoeringswet BES.

21 In accordance with treaties, with extra language rights in the domain of criminal law.
} 
judicial system as well, the perceived inadequateness of Papiamento as a language for governance, the judiciary and education, and the expected high expenses for translation and interpreting services. On the other hand, in the report on a recent study on language in the judicial system in the BES islands, the Dutch Law Enforcement council 'does see cause for restricting the use of Dutch within law enforcement where possible' (Raad voor de Rechtshandhaving, 2017, p. 13).

We will make the point that despite the presumed equality of Papiamento and Dutch in the official languages ordinance, Aruban law confirms the dominant position of Dutch over Papiamento as a continuation of European Dutch state tradition in government, education and law/legal practice. The Official Languages Act was a start, but this start is not yet enough to reach full access and inclusion in legislation, governance and education.

\section{The Official Languages Act Aruba and the Primary Education Act}

In 2003, the Aruban Official Languages Act was passed, bringing about an apparently big change in official language policy. Before 2003 Dutch was officially the only language with legal status for governance, legislation and education in Aruba, but with the introduction of this act, the status of Papiamento was confirmed in law and citizens and government officials in Aruba were granted the formal right to use Papiamento as well as Dutch in oral and written interactions. Article 2 of this act stipulates that Papiamento and Dutch are the official languages of Aruba. ${ }^{22}$ Interesting is that in this article, contrary to common practice, Papiamento is named before Dutch, maybe even symbolically contrary to alphabetical order and suggesting that Papiamento has risen to a full status. Article 3 regulates language use between citizens and administrative bodies. It empowers everyone to use both Papiamento and Dutch in oral and written interaction with the government ${ }^{23}$ and empowers government to use both languages in oral and written interaction (both with citizens as well as internally). ${ }^{24}$ For written documents, a translation in the other official language can be requested by the citizen that can prove to have an interest in that document. The term for the translation is four weeks and the government body that supplies the translation can require the payment of a non-specified fee for the translation except for special conditions accord- ing to the Aruban administrative legislation. ${ }^{25}$ No specific stipulations or guarantees are made for oral communication. ${ }^{26}$ As such, this legislation fails to provide the authority for citizens to demand government communication in two languages.

Article 4 of the same languages act regulates the formulation of oaths, promises and declarations. This article stipulates that the wording of an oath is legally prescribed and that instead of the legally prescribed Dutch wording, one has the authority to pronounce the equivalent text in Papiamento, after which the article prescribes the Papiamento wording for oaths, promises and declarations. ${ }^{27}$ This article has been formulated in such a way that Dutch is represented as the norm, and Papiamento as an alternative for the language that is the norm that can be used instead of the norm. This article has not been written from a perspective of putting Papiamento on the same level as Dutch, but from the perspective of allowing Papiamento next to Dutch. A more neutral formulation would simply stipulate that you can use either one language or the other.

Article 5 is exclusive: it stipulates that the language of legislation is Dutch, and article 6 stipulates that the official legal language, as stipulated in article 1 of criminal proceedings, is Dutch. This is interesting; every citizen is supposed to know the laws of the country and apparently these laws are only provided in one language, Dutch. When confronted with criminal charges this is a very threatening thing a government body can do to citizen: suddenly confront him with a monolingual Dutch system. Despite the fact that in practice Papiamento and also English are regularly used in court, the Dutch orientation of the judges does not support accessibility of the court (the majority of the judges consists of temporary Dutch judges), nor does the false assumption that Aruban suspects speak Dutch. The use of interpreters and translators does not solve that issue, as the availability of interpreters is a minimum requirement, not a guarantee of reliability, and in general the need for an interpreter is based upon the suspect's or lawyer's disputable (self-)assessment of the suspect's own language skills. As such, the current legislation frames the majority language speaking Aruban in a minority language position for which special facilities have to be created to adhere to minimal international guarantees of orderly process.

Article 9.1 of the Primary Education Act ${ }^{28}$ (1989) states that Papiamento is the language of instruction

\footnotetext{
22 Article 2 Landsverordening officiële talen Aruba: De officiële talen van Aruba zijn het Papiamento en het Nederlands.

${ }^{23}$ Article 3.1 Landsverordening officiële talen Aruba: Een ieder is bevoegd zowel het Papiamento als het Nederlands te gebruiken in the mondelinge en het schriftelijke verkeer met een bestuursorgaan.

${ }^{24}$ Article 3.2 Landsverordening officiële talen Aruba: Een bestuursorgaan is in het mondelinge en schriftelijke verkeer bevoegd zowel het Papiamento als het Nederlands te gebruiken.

25 Landsverordening Administratieve Rechtspraak (AB 1993 no. 45).

${ }^{26}$ Article 3.4 Landsverordening officiële talen Aruba: Indien een bestuursorgaan een schriftelijk stuk heeft gesteld in één van de officiële talen, verstrekt het daarvan op verzoek binnen vier weken een vertaling in de andere officiële taal, indien de verzoeker belanghebbende is. Het bestuursorgaan kan voor het vertalen een vergoeding verlangen.

27 Article 4.1 Landsverordening officiële talen Aruba: Hij die ter uitvoering van een wettelijk voorschrift mondeling een eed, belofte of verklaring moet afleggen, is bevoegd in plaats van de wettelijk in het Nederlands voorgeschreven woorden de daarmee in het Papiamento overeenkomende woorden uit te spreken, tenzij de woorden van de eed, belofte of verklaring bij of mede bij de Staatsregeling van Aruba zijn vastgelegd.

28 Article 9.1 Landsverordening Basisonderwijs Aruba.
} 
for the first two years of education; the following years, Dutch is the language of instruction. Only after explicit approval by the Minister of education, Papiamento can be used as an instruction language. Article 9.3 states that the Minister can deviate from article 9.1 for one or more courses for languages other than Papiamento and Dutch. ${ }^{29}$

These legal stipulations are a strong representation of the complexity of the roles and uses of the former colonizer's language, Dutch, and the predominantly Papiamento-speaking society of Aruba, and the way in which legislators fail to create legal constructs that are sufficiently inclusive. The state tradition of Dutch governance, the judiciary and education is continued through the legal protection of Dutch, and there is a lack of legal promotion of Papiamento in governance and all other domains, as such continuing some of the former colonizer's language policies without direct interference from the former colonizer. At best, current language laws in Aruba can be seen as symbolic legislation that, in the end, reinforces the role of Dutch in certain domains of the judiciary and education and fails to provide the population with guarantees for the use of language in communication with government in written and oral form.

\section{Conclusions}

Multidisciplinary research agendas for the development and acceptance of inclusive language policies in other multilingual societies and our description and analysis of the LPP of the Caribbean countries and territories of the Kingdom of the Netherlands suggest that the current language policy and legislation does not lead to a linguistically inclusive society in which the majority of the island's populations is optimally included. On an individual basis there are sincere efforts to reach inclusive solutions. The complexity of this issue-institutional aspects which possibly concern the future of the Kingdom are at stake-sometimes seems to be the excuse to deny the problem. We are convinced that that should not be the case. Multidisciplinary research and analysis of current policy and practice must lead to approaches of the language challenges in the Caribbean part of the Kingdom of the Netherlands that could also be exemplary for similar states with similar challenges.

As far as they are relevant for the Caribbean part of the Kingdom of the Netherlands, international treaties seem to pose no legal problems. However, empirical data is lacking. Because of the applicability of special (treatybased) demands, special attention is paid to criminal law, often neglecting the study of LPP in governance and administrative and civil law. Regarding the (binding) fundamental principles, a deeper study of the literature on language policy and law in other multilingual societies should reveal possible bottlenecks in social inclusion.

From this analysis, we can conclude that LPP in the Caribbean countries and territories of the Kingdom of the Netherlands have features that strongly reflect (post)colonial relations. However, LPP is not the Kingdom's responsibility, it is the responsibility of the (autonomous) countries of the Kingdom. Argumentation for the unifying function of the Dutch language in the Kingdom of the Netherlands, also referring to the concordance principle in the Charter for the Kingdom of the Netherlands, is another postcolonial complexity of this study of LPP in the Caribbean.

The position and need for judges (in the case of the Dutch Caribbean, also supervisors) from the European part of the Netherlands seems to be important for LPP in the judiciary and legislation in the Caribbean. On the other hand, court (and supervisory) procedures are very exceptional in the day-to-day life of the populations of these islands, and therefore cannot be a decisive criterion for LPP in the Caribbean. In practice, the civilian in the legal process in the Caribbean is often framed as a 'foreign language speaker' of the judicial system.

This publication is a description of aspects of legislation at different levels of authority on LPP. Conclusions are crystal-clear, however, there is currently a need for further investigation of underlying and hidden challenges and solutions in education, legislation, governance and the judiciary along the lines of practices of inclusion and exclusion on the basis of language. The execution of that follow-up research should result in multidisciplinary advice on the inclusive alignment of policy legislation, law, governance and practice.

\section{Acknowledgments}

The authors would like to express their gratitude for the kind support from Carlos Rodriguez who took his time to proof read the manuscript.

\section{Conflict of Interests}

The authors declare no conflict of interests.

\section{References}

Ball, S. (1993). What is policy? Texts, trajectories and toolboxes. Discourse, 13(2), 10-17.

Baptista, M., Brito, I., \& Bangura, S. (2010). Cape Verdean in education. In B. Migge, I. Léglise, \& A. Bartens (Eds.), Creoles in education: An appraisal of current programs and projects (pp. 273-296). Amsterdam and Philadelphia: John Benjamins.

DeGraff, M. (2016). Input to United Nations Office of the High Commissioner for Human Rights on the protection of the rights of the child in the implementation of the 2030 Agenda for Sustainable Development. Washington: Linguistic Society of America.

Dijkhoff, M., \& Pereira, J. (2010). Language and education in Aruba, Bonaire and Curaçao. In B. Migge, I. Léglise \& A. Bartens (Eds.), Creoles in education: An appraisal

${ }^{29}$ Article 9.3 Landsverordening Basisonderwijs Aruba. 
of current programs and projects (pp. 237-272). Amsterdam and Philadelphia: John Benjamins.

Garrett, H. (2008). Language use, language attitude and identity among Papiamentu speakers. In N. Faraclas \& C. Weijer (Eds.), Linguistic studies on Papiamentu (pp. 27-45). Curaçao and Puerto Rico: FPI/UNA/UPR.

Johnson, D. C. (2006). Comparing the trajectories of educational change and policy transfer in developing countries. Oxford Review of Education, 32(5), 679-696.

Lallmahomed-Aumeerally, N. (2005). Minority rights and anti-discrimination policy in Mauritius: The case of 'Malaise Creole'. International Journal of Cultural Policy, 23(4), 446-463.

Liasidou, A. (2012). Inclusive education, politics and policymaking. London and New York: Continuum.

Mijts, E. (2014). Recentering the focus in discourse on education in postcolonial small island states: The case of Aruba. In N. Faraclas, R. Severing, C. Weijer, E. Echteld, \& W. Rutgers (Eds.), Creole connections (pp. 121-128). Curaçao and Puerto Rico: FPI/UNA/UPR.

Mijts, E. (2015). Discourse over de Nederlandse taal en onderwijs in de Caraïben. In CARAN 2013 (pp. 61-67). Paramaribo: IOL.

Mijts, E., Kester, E. P., Lozano Cosme, J., \& Faraclas, N. (2014). Applied linguistics in St. Eustatius: How can linguists contribute constructively to debates concerning the languages of instruction in Caribbean schools? In N. Faraclas, R. Severing, C. Weijer, E. Echteld, \& W. Rutgers (Eds.), Creole connections (pp. 173-194). Curaçao and Puerto Rico: FPI/UNA/UPR.

Pereira, J. (2012). How to begin healing a festering wound: Papiamento, community and education in Aruba. In N. Faraclas, R. Esperano Severing, C. M. Roose-Weijer, \& E. Echteld (Eds.), Crossing shifting boundaries: Language and changing political status in Aruba, Bonaire and Curaçao (pp. 87-93). Curaçao and Puerto Rico: FPI/UNA/UPR.
Prins-Winkel, A. C. (1973). Kabes Duru? Een onderzoek naar de onderwijssituatie op de Benedenwindse eilanden van de Nederlandse Antillen, in verband met het probleem van de vreemde voertaal bij het onderwijs. Assen: Van Gorcum.

Raad voor de Rechtshandhaving. (2017). Consequenties van meertaligheid voor de rechtshandhaving in Caribisch Nederland: Als de uitzondering regel is. Retrieved from https://www.rijksoverheid.nl/documen ten/rapporten/2017/07/03/tk-bijlage-raad-voor-derechtshandhaving

Reintjes, J. (2010). De rechtstaal in Antilliaanse Strafzaken. In TAR-Justicia 2010-1 (pp. 1-9).

Santos do Nascimento, R. (2017). Het Koninkrijk ontsluierd (PhD Dissertation). Apeldoorn and Antwerpen: Maklu.

Sonntag, S., \& Cardinal, L. (2015). Introduction. State traditions and language regimes: Conceptualizing language policy choices. In L. Cardinal \& S. Sonntag (Eds.), State traditions and language regimes (pp. 3-26). Montreal and Kingston: McGill-Queen's University Press.

Tollefson, J. (2013a). Critical issues in language policy in education. In J. Tollefson (Ed.), Language policies in education: Critical issues (pp. 3-10). New York and London: Routledge.

Tollefson, J. (2013b). Language policy in a time of crisis and transformation. In J. Tollefson (Ed.), Language policies in education: Critical issues (pp. 3-10). New York and London: Routledge.

Van der Velden, B. (2008). Salta cacho, salta su rabu. Over de ontwikkeling van het gebruik van Papiaments als rechts- en bestuurstaal. In UNA publicaties 2007 (pp. 163-198). Curaçao: UNA.

Winkel, N. (1955). Het taalprobleem in het Antilliaanse onderwijs. In Christoffel, 1(2), 68-78. Retrieved from http://www.jstor.org/stable/41850768

\section{About the Authors}

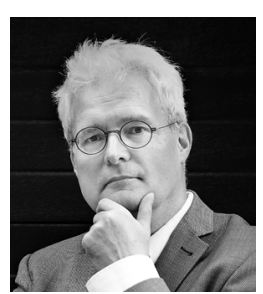

Herman Bröring is Professor of Integrative Law Studies at the University of Groningen and Visiting Professor of Administrative Law at the University of Aruba. He is participating in the research program Public Trust and Public Law Groningen and in the Groningen Centre for European Financial Services Law. His areas of research are: soft law (non-statutory rules, quasi-legislation, administrative rules, policy rules, codes of practice, guidelines, et cetera); law enforcement; participation in public decision making; public law of the Caribbean territories of the Kingdom of the Netherlands.

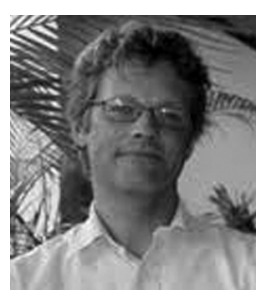

Eric Mijts studied Linguistics and Literature at the University of Antwerp and is specialized in sociolinguistics. In 2000, he joined the University of Aruba where he works as researcher and lecturer in skills and linguistics as well as an initiator of educational innovation and multidisciplinary and interdisciplinary research programs. As a researcher he is affiliated to the University of Antwerp and Ghent University. He coordinates the Academic Foundation Year and the UAUCU student research exchange. His research and publications focus on multilingualism, language policy and planning, identity and social inclusion/exclusion processes. 